\title{
Cytogenetic and interphase Fluorescence in Situ Hybridization studies in patients with multiple myeloma
}

\author{
G Perumal $^{1 *}$, RS Chandra ${ }^{2}$, P Prabu $^{1}$, N Indhumathi ${ }^{1}$, Anil Tarigopula ${ }^{1}$, Rama Mani ${ }^{1}$ \\ From International Conference on Human Genetics and 39th Annual Meeting of the Indian Society of \\ Human Genetics (ISHG) \\ Ahmadabad, India. 23-25 January 2013
}

\section{Background}

Multiple myeloma (MM) is characterized by the clonal proliferation and accumulation of malignant plasma cells in the bone marrow, monoclonal protein in the blood or urine and associated organ dysfunction. Some patients may show a slow progressive evolution from monoclonal gammopathy of undetermined significance while others may be associated with features of high clonal aggressiveness such as plasma cell leukemia or extramedullary plasmacytomas. Chromosomal abnormalities (mainly IgH translocations and trisomies) have been shown to be of prognostic significance in MM. Interphase fluorescence in situ hybridization (i-FISH), in particular, has been much more effective in identifying these trisomies/ monosomies and specific translocations.

\section{Materials and methods}

The bone marrow aspirates were processed for conventional cytogenetic and interphase FISH analyses using three probes to detect del(13)(q14.3), $\mathrm{t}(4 ; 14)(\mathrm{p} 16.3: \mathrm{q} 32)$ and $\operatorname{del}(17)(\mathrm{p} 13.1)$. A total of 30 newly diagnosed patients were studied between May 2012 and March 2013. The affected were mostly elderly people with median age of 55 years (range: 32 to 80 years) at the time of diagnosis. There were 21 males and 9 females.

\section{Results and conclusions}

Chromosomal abnormalities were detected in only 7 patients because of the low proliferation rate of plasma cells and the non-availability of analyzable metaphases.

\footnotetext{
* Correspondence: perumalyogi@gmail.com

'Department of Molecular Biology and Cytogenetics, Apollo Hospitals, No.

21, Greams Lane, Off. Greams Road, Chennai-600 006, Tamilnadu, India

Full list of author information is available at the end of the article
}

On the other hand, i-FISH revealed an abnormality in 14 patients and a normal pattern for the selected probes in the remaining 16 patients. The most frequent abnormality was found to be 13 monosomy (complete/ partial) in 13 cases followed by $t(4 ; 14)$ seen in 4 patients. However these abnormalities were not recognized in the karyograms. None of the cases showed a p53 deletion. Further studies employing the complete FISH panel are required for better diagnosis and prognosis.

\section{Authors' details}

'Department of Molecular Biology and Cytogenetics, Apollo Hospitals, No. 21, Greams Lane, Off. Greams Road, Chennai-600 006, Tamilnadu, India. ${ }^{2}$ Department of Genetics, Dr. ALM PG. Institute of Basic Medical Sciences, University of Madras, Taramani, Chennai - 600113, Tamilnadu, India.

Published: 21 January 2014

doi:10.1186/1755-8166-7-S1-P20

Cite this article as: Perumal et al:: Cytogenetic and interphase Fluorescence in Situ Hybridization studies in patients with multiple myeloma. Molecular Cytogenetics 2014 7(Suppl 1):P20.

Submit your next manuscript to BioMed Central and take full advantage of:

- Convenient online submission

- Thorough peer review

- No space constraints or color figure charges

- Immediate publication on acceptance

- Inclusion in PubMed, CAS, Scopus and Google Scholar

- Research which is freely available for redistribution

Submit your manuscript at www.biomedcentral.com/submit
() Biomed Central 